\title{
EurSafety Health-net: development of an EURegional infection control quality certificate for nursing homes
}

\author{
A Eikelenboom-Boskamp ${ }^{1,2^{*}}$, A Haenen ${ }^{3}$, R Koopmans $^{4}$, A Voss $^{1,2}$ \\ From International Conference on Prevention \& Infection Control (ICPIC 2011) \\ Geneva, Switzerland. 29 June - 2 July 2011
}

\section{Introduction / objectives}

As part of the EurSafety Health-net project, a cross-border German-Dutch healthcare project to reduce HAIs, and in cooperation with regional specialists in care for the elderly, we developed an infection control quality improvement program for nursing homes. Aim of this multi-year project is to implement a complete infection control program for nursing homes in a step-by-step fashion.

\section{Methods}

A multi-step plan, each consisting of 10 measures, was developed to improve infection control practices in nursing homes. The audit was done by an EurSafety auditteam. Organizations reaching 5 of the 10 criteria receive a certificate and have up to 3 years to fullfil the remaining criteria, before advancing to the next step. Participation and certification are depicted on a website accessible for the public.

\section{Results}

The first certificates have been distributed in January 2011 to 27 institutions in the Nijmegen region. The initial ten criteria consisted of structure and process criteria, as well as HAI-prevalence and UTI-incidence studies. The poster will describe the criteria in detail.

\section{Conclusion}

Due to the frequent exchange of patients between healthcare facilities, Infection control programs in long-term care facilities become increasingly important. The EurSafety quality program stimulates LTCF's to structurally improve

${ }^{1}$ Medical Microbiology, Radboud University Medical Centre, Netherlands Full list of author information is available at the end of the article their performance, while the certificate gives visibility of their efforts to all stakeholders.

\section{Disclosure of interest}

None declared.

\section{Author details}

${ }^{1}$ Medical Microbiology, Radboud University Medical Centre, Netherlands. ${ }^{2}$ Medical Microbiology and Infectious Diseases, Canisius Wilhelmina Hospital, Nijmegen, Netherlands. ${ }^{3}$ Epidemiology and Surveillance, National Institute for Public Health and the Environment, Bilthoven, Netherlands. ${ }^{4}$ Primary and Community Care, Radboud University Medical Centre, Nijmegen,

Netherlands.

Published: 29 June 2011

doi:10.1186/1753-6561-5-S6-P164

Cite this article as: Eikelenboom-Boskamp et al.: EurSafety Health-net: development of an EURegional infection control quality certificate for nursing homes. BMC Proceedings 2011 5(Suppl 6):P164.

Submit your next manuscript to BioMed Central and take full advantage of:

- Convenient online submission

- Thorough peer review

- No space constraints or color figure charges

- Immediate publication on acceptance

- Inclusion in PubMed, CAS, Scopus and Google Scholar

- Research which is freely available for redistribution 